\title{
E-government: A Catalyst to Good Governance in China
}

\author{
Ling Lan \\ Tianjin University of Finance and Economics, Tianjin, China \\ llinglan@eyou.com
}

\begin{abstract}
The paper first analyses the characteristics of governance in the information age, illustrates the advantages of E-government services; Second, deals with the implications and key elements for good E-governance; finally points out the urgent tasks for good E-governance in China, emphasizing governmental responsibility on primary education, human resource cultivation, sustainable social and economic development, etc.
\end{abstract}

\section{Introduction}

Since the mid -1990s, Chinese government, together with other governments around the world, has been launching its ambitious National E-government project, so as to embracing the brand new era of information technology, building China into a modern democratic and knowledge-oriented society.

E-government, by definition, refers to the use of information and communication technology (ICT) to promote more efficient and cost-effective government, facilitate more convenient government services, allow greater public access to information, and make government more accountable to their citizens. It is not merely a technology term or event, but rather a profound revolution. Just as the point of view of the United Nations that E-government is a government that applies ICT to transform its internal and external relationship, ${ }^{1}$ hereby I argue strongly that the E-government project, if be properly carried through, may work as some kind of catalyst to promote good governance in China, just as in other countries of the world. The project is not only our ideal vision in the future, but also a strong belief that our country, our people and our society will benefit a great deal from the E-government Strategy as well as from the program in its every aspect.

\section{Governance in the Information Age}

In recent years, the concept of Good governance has gained more and more recognition throughout the world, a number of governance indicators, testing data and links between good governance and economic outcomes, have been designed and widely used in the field of academic research. These Indicators measure different aspects of

1 Department of economic and Social Affairs, United nations, 2003 World public sector report 2003 Egovernment at the crossroads.pp.2. New York. 
the quality of governance, such as the severity of corruption, the extent of civil liberties, the bureaucratic efficiency, the rule of law, the predictability of policymaking, etc. Citizens of both developing and developed countries are increasingly aware of the costs of poor governance, and they are demanding better performance on the part of their governments, they believe that good governance is a necessary condition for long-term economic growth and people's welfare.

Apparently, governance needs technology basis; and good governance needs more advanced technology background or atmospheres. The advent of Information age makes it possible for governments to pursue managerial or governing excellence. Egovernment initiatives around the world certainly have playing an important role to redefine the fundamental elements of government, improve government performance, as well as to change the traditional governance institutions and regimes globally.

In the Information Age, the traditional governance paradigm has transferred into a new pattern characterized by the overwhelmingly use of digital technology, which may be called Electronic Governance, and from that, the governments, operating in the world for century's long, have begun their new existences, the unprecedented Egovernment now come into being. If some one ask what is the advantage of Egovernment? It will not be a short list, we can promptly illustrates a categories of advantages of E-government, among them including:

1. Improving services to citizens. E-government can offer numerous possibilities for improving a nation's public sector responds to the basic needs of its citizens. People always want information or services delivered quickly and easily. Egovernment means people's needs can be met in a more timely, tailored, and convenient ways, while maintaining their privacy and the security of their personal information, that is really great.

2. Improving the productivity and efficiency of government agencies. Today, the governmental agencies are wanted to deliver "outcomes" and outputs, achieve better results for serving people' various needs. This will involve agencies working more effectively across their traditional boundaries and collaborating with one anther. Egovernment will satisfy this need by sharing information between departments (G2G), with businesses (G2B) and with citizens (G2C). Which will strengthen the integration of structures and processes of governmental bureaucracy, and make government agencies operate more efficiently.

3. Strengthening the legal system and law enforcement. Governments are the largest purchasers in all economies, and for both moral and political reasons they should buy goods and services in the best way possible. One dollar paid in excess of the best possible price is a dollar less to provide health care, social security or public housing. By fostering transparency, and empowering people to participate in the political processes, e-government will strengthen the legal system and law enforcement; make policy processes more open and consultative.

4. Promoting the development of priority economic sectors and regions. Under egovernment project, government must observe market principles, behave in a promarket way, consequently government will minimize its intervention to business on the one hand; and promote the development of priority economic sectors and regions on the other hand, for example, to promote the growth of the software industry and train qualified experts in IT field, take the advantage of economic of scale, set up Industrial clusters, and boost remote and rural area's development. 


\section{Improving the quality of life for vulnerable people and disadvantaged communities} E-government is an aspect of the whole issue of governance, the whole issue of economic and social development concerning the question of poverty reduction, empower the poor and vulnerable people in a society, it means sharing the opportunity for development. Responsible E-government project cannot simply ignore the fact that technology has the prospect of giving a huge advantage to some parts of the country, whereas leaving behind many other parts of the country with an even greater gap to catch up. Sharing benefits without frontier is the soul of technology revolution.

6. Advancing public management performance and promoting good governance. Egovernment will eventually transform the processes and structures of government to create a public administration regime with less hierarchical red tapes, it will be citizen-centered, not bureaucracy-centered; results-oriented, other than inputsoriented, it will working in further more effective and efficient ways. The marketbased behavior of E-government will actively promote entrepreneurship and innovation process. Governmental agencies will empower civil servants to serve citizens better and to be more responsive to their needs, so that the dream of reinventing government devised by David Osbrne and Ted Gaebler will become reality.

In the information age, governance needs a fundamental revolution. With the technologies to implement electronic governance already available and its importance understood by the leaders of our country, managerial issues are of key importance, Change in the mindset of the people particularly at the top levels in the bureaucracy is critical because it is the elite group who provide the leadership. Now E-Government in China is in the initial stage, we should follow the logic of its development, and build successful E-Government project with Chinese characteristics.

\section{Good Governance under E-government Project}

China is a big country with a large population and extensive territory the implement of E-Government project is naturally important, even critical to China's social and economic development. It reported that from 1994, the Internet has developed quickly in every aspects of the nation, the most famous E-Government project in China is socalled" Golden Projects", which started from 1993, aimed at developing an information economy and strengthening administrative capabilities.

The Golden Projects initially comprised three elements known as Golden Bridge, Golden Card and Golden Customs. Golden Bridge is the infrastructure for 'informatizing' the national economy, its mission is to build the infrastructure backbone over which other information services will run; Golden Card project, initiated in 1995, aimed at creating a unified payment system to allow the widespread use of credit and debit cards across China; the Golden Customs project was intended to create an integrated data communications system connecting foreign trade companies, banks, and the customs and tax authorities, so as to lay a foundation for E-business in China.

The success of the three pilot projects paved the way for a range of other Golden Projects, including Golden Sea project, building a data network directly to top CCP and government leaders; the Golden Tax project, aimed at modernizing the work of 
tax collection in the country, The whole Golden Projects, its purpose and participants, is illustrated below in the table 1:

According to Chinese ancient tradition, golden color is so noble, so auspicious that the use of the color was restricted to some kind of special occasions. Giving the name of "Golden projects" to E- government and other E-projects, indicating Chinese government has attached great importance to the projects and taken strong commitment to carry them through. Beside the "government online project", China has also launched "corporation online project" and "family online project". Nowadays, Internet is becoming the indispensable thing in daily life of ordinary Chinese people, we have all the provinces and all the state bureaus online, and a number of E-Government services are available on the Internet. Chinese Citizens are encouraged to access EGovernment services as their convenience.

Table 1. The Golden Projects in China

\begin{tabular}{|c|c|c|}
\hline NAME & $\begin{array}{c}\text { MAIN } \\
\text { PARTICIPANTS } \\
\end{array}$ & PURPOSE \\
\hline $\begin{array}{l}\text { Golden Bridge } \\
\text { (JinQiao) }\end{array}$ & $\begin{array}{l}\text { MII; MEI; State } \\
\text { Information } \\
\text { Center; JiTong }\end{array}$ & $\begin{array}{l}\text { To build a public network backbone and } \\
\text { international Net work interface capable of } \\
\text { transmitting data, voice, image and multi- } \\
\text { media information. }\end{array}$ \\
\hline $\begin{array}{l}\text { Golden Card } \\
\text { (Jin Ka) }\end{array}$ & $\begin{array}{l}\text { PBoC; MII; Minis- } \\
\text { try of Internal } \\
\text { Trade; Great Wall } \\
\text { Computer Co }\end{array}$ & $\begin{array}{l}\text { To establish an electronic-based financial } \\
\text { transaction system and information service; } \\
\text { to have } 200 \text { million credit cards in use } \\
\text { across } 400 \text { cities by } 2000-2003 \text {. }\end{array}$ \\
\hline $\begin{array}{l}\text { Golden } \\
\text { Customs } \\
\text { (Jin Guan) }\end{array}$ & $\begin{array}{l}\text { MOFTEC; Customs } \\
\text { Dept; JiTong }\end{array}$ & $\begin{array}{l}\text { To establish networks capable of handling } \\
\text { foreign -trade taxes, foreign currency set- } \\
\text { tlements, domestic returns, quota manage- } \\
\text { ment systems, an electronic data inter- } \\
\text { change (EDI) and an import-export statisti- } \\
\text { cal database. }\end{array}$ \\
\hline $\begin{array}{l}\text { Golden Sea } \\
\text { (Jin Hai) }\end{array}$ & $\begin{array}{l}\text { State Statistical } \\
\text { Bureau; PBoC; } \\
\text { State Information } \\
\text { Center }\end{array}$ & $\begin{array}{l}\text { To build a data network linking top gov- } \\
\text { ernment leaders with other institutions, or- } \\
\text { ganizations and offices under the direct ju- } \\
\text { risdiction of the communist Party Central } \\
\text { committee. }\end{array}$ \\
\hline $\begin{array}{l}\text { Golden Macro } \\
\text { (JinHong) }\end{array}$ & $\begin{array}{l}\text { China Im-Ex Bank; } \\
\text { Ministry of } \\
\text { Finance; State In- } \\
\text { formation Center }\end{array}$ & $\begin{array}{l}\text { To develop a state economic and policy } \\
\text { support system by setting up databases uni- } \\
\text { fying industrials, taxation, prices, invest- } \\
\text { ments, resources, capital energy, transporta- } \\
\text { tion and information exchange. }\end{array}$ \\
\hline $\begin{array}{l}\text { Golden Tax } \\
\text { (Jin Shui) }\end{array}$ & $\begin{array}{l}\text { Ministry of Finance; } \\
\text { MII; State Taxation } \\
\text { Bureau; Great Wall } \\
\text { Computer Co }\end{array}$ & $\begin{array}{l}\text { To make use of computerized work unit tax } \\
\text { receipts and direct bank connections to aid } \\
\text { the flow and use of funds across China. }\end{array}$ \\
\hline $\begin{array}{l}\text { Golden } \\
\text { Intelligence } \\
\text { (Jin Zhi) }\end{array}$ & $\begin{array}{l}\text { State Education } \\
\text { Commission }\end{array}$ & $\begin{array}{l}\text { To enable teachers and research profession- } \\
\text { als to have timely and precise information } \\
\text { and to enable international and local com- } \\
\text { munication and cooperation. }\end{array}$ \\
\hline
\end{tabular}




\begin{tabular}{|c|c|c|}
\hline $\begin{array}{l}\text { Golden } \\
\text { Enterprise } \\
\text { (Jin Qi) }\end{array}$ & $\begin{array}{l}\text { State Economic and } \\
\text { Trade Commission }\end{array}$ & $\begin{array}{l}\text { To design and build an integrated enterprise } \\
\text { target (quota) and distribution system; to } \\
\text { build a countrywide enterprise and product } \\
\text { database. }\end{array}$ \\
\hline $\begin{array}{l}\text { Olden } \\
\text { Agriculture } \\
\text { (Jin Nong) }\end{array}$ & $\begin{array}{l}\text { Ministry of } \\
\text { Agriculture }\end{array}$ & $\begin{array}{l}\text { To develop and monitor agricultural super- } \\
\text { visory committees, and the calculation and } \\
\text { forecasting system. }\end{array}$ \\
\hline $\begin{array}{l}\text { Golden Health } \\
\text { (Jin Wei) }\end{array}$ & Ministry of Health & $\begin{array}{l}\text { To develop and apply computer technology, } \\
\text { communications technology and scientific } \\
\text { information distribution to the medical sec- } \\
\text { tor. }\end{array}$ \\
\hline $\begin{array}{l}\text { Golden } \\
\text { Information } \\
\text { (Jin Xin) }\end{array}$ & $\begin{array}{l}\text { State Statistical } \\
\text { Bureau }\end{array}$ & To develop real-time information flows. \\
\hline $\begin{array}{l}\text { Golden Housing } \\
\text { (Jin Jia) }\end{array}$ & & To create a property information network. \\
\hline $\begin{array}{l}\text { Golden Switch } \\
\text { (Jin Kai) }\end{array}$ & $\begin{array}{l}\text { Ministry of Infor- } \\
\text { mation Industry }\end{array}$ & $\begin{array}{l}\text { To build China's domestic digital switch } \\
\text { manufacturing industry. }\end{array}$ \\
\hline $\begin{array}{l}\text { Golden } \\
\text { Cellular } \\
\text { (Jin Feng) }\end{array}$ & $\begin{array}{l}\text { Ministry of Infor- } \\
\text { mation Industry }\end{array}$ & $\begin{array}{l}\text { To provide the basis for a coordinated mo-- } \\
\text { bile communications strategy, and to de- } \\
\text { velop national roaming standards and sys- } \\
\text { tems. }\end{array}$ \\
\hline
\end{tabular}

Source: Peter Lovelock and John Ure. E-Government In China., www.trp.hku.hk.

However, we cannot stop here, E-Government is a long march, we still have a long way to go to reach its destination. E-government does not function well just because government buys more computers and puts up more websites on intent. It does not function even governmental online service delivery is more efficient and less costly than other channels. The goal of E-Government is not so simple; it cannot be reached automatically without down to earth hard working. What we have done is only the tangible infrastructures for E-government. It is the intangible infrastructures that are the most important elements for good government performance and good governance. In perspective of ICT development, China is surely one of the most expanding and growing countries, what more Interesting, however, is what approaches it should adopt, especially for a country with a long tradition of strong state administration, to realize democratic and civic participate goal. We know, of course, the feasible path may be different from those of developed democratic countries; we should blaze a way in democratic governance via E-governance. Dr. James D. Wolfensohn, President of The World Bank, once argued: "Civil society is probably the largest single factor in development..."2 thereby only if civil society could operated well upon Egovernment infrastructures, could that of good governance goal be eventually

2 James Wolfensohn, Speech at the World Bank/Development Gateway Conference:E-government in Developing Countries. Washington, D.C.June 11, 2001. 
reached. The infrastructures supporting civil society movement is mainly intangible, such as social, cultural, and institutional elements, which are also the pillars of national Integrity. B. Shadrach, an expert from Transparency International explained that there are eight concrete factors embedded in the mainstay of national Integrity, i.e., 1 Public Awareness; 2 Public anti-corruption strategies; 3 Public participation; 4 Watch-dog agencies; 5 The Judiciary; 6 The Media; 7 The private sector; 8 International co-operation. These factors are interdependent, identifying opportunities for reinforcing the fight against corruption. ${ }^{3}$

Economic theory expounds on the importance of information on economic outcomes either through its direct effect on prices and quantities or through its effect on other factors such as institutions and the quality of governance. It is well known transparency being a key point of good governance, countries with better information flows also govern better, therefore the most important role that E-government program bore is to promote government transparency and thus reduce the opportunities of corruption, good governance is among other things, particularly transparent and accountable, it is also effective and equitable. We should kept a vigilant guard over the E-corruption that might be produced by corruption-prone public organizations, and explore the possibility of developing integrity pacts (TIIP) for E-government services.

\section{Knowledge Management via E-government Project}

Now let us take a different look at E-government project in China, we need to have an awareness of, first and foremost, the challenges and difficulties that facing by Chinese government, realizing it will be difficult for China, with so large a population and enormous regional disparity, to realize the E-Government mission, it will be an arduous process obviously, requiring good plan, strong political commitment, sustained dedication, and sufficient public investment. Therefore, we should also bear in mind the E-government project is simultaneously a process of knowledge creation, management and dissemination through governmental efforts in pushing information and communications technology in our country, for example, government sponsored webschool system that can reach remote rural areas, disseminating knowledge to those local poor children and dwellers who do not have the opportunities of getting in touch with outside world, it is E-government project and its ancillary program that bring necessary knowledge and technical help to them, that can enlighten and empower them , and absolutely change their fate in the future.

Building E-government architecture is a progressive process, however, different countries should have different strategies, the United Nations Division for Public Economics and Public Administration outlined five general stages to successful Egovernment, 1 Emerging stage: A government web presence is established through a few independent official sites, but Information is limited, basic and static; 2 Enhanced stage: Content and information is updated with greater regularity, 3 Interactive stage: Users can download forms, contact officials, and make appointments and requesths; 4

3 B. Shadrach. eGovernment for Transparency. International conference on eGovernment for Development Palermo, Italy, 10-11 April 2002 
Transactional stage: Users can actually pay for services or conduct financial transactions online; 5 Seamless stage: Total integration of e-functions and services across administrative and departmental boundaries. But according to the E-government handbook for developing countries, which is the research result of the Project of the Information for Development by The Center for Democracy \& Technology, the evolution of E-government can be simplified into three phases, 1 Publish stage :Using ICT to expand access to government; 2 Interact stage: broadening civic participation in government; 3 Transact stage: Making government services available on line.

It seems that China's E-government build is not arranged strictly in consecutive order, but starting from several stages at the same time, yet every stage has not been developed to its perfect pattern until now. The challenges we are facing today is twoside, one is keeping up with the rapid development of information technology, putting a curb on the problem of brain- drain, and increasing national R\&D investment on high tech, etc, the other, however, is waging a struggle to wipe out poverty in some remote and rural regions of the country, where people's living conditions are so rough that they don not have enough food or drinking water, they suffer from disease, plague, drought or flood, kids do not have enough opportunity of primary education, let alone talking with them the high technology or digital revolution. The most urgent task for China to pursue good governance is not just reducing the phenomenon of poverty, but eradicating the rootstock of poverty, i.e. the institutional basis upon which the poverty phenomenon being duplicated, passed down and accelerated one generation to another. Knowledge is the most important factor, more than land, tools and labors, to determine the fortunes of the poor. Our vision for China is a civilized and learning society not only built on the high tech but also on honest, discipline and other moral purpose. Our ancestor once created a splendid treasure of civilization; Chinese architecture, literature, calligraphy, porcelain, medicine, acupuncture and even our martial arts are famous all over the world. Keep on our tradition, the present government of China certainly should assume the responsibility of educate its people from now on, build solid infrastructures for E-government regimes technologically and morally.

Citing the data from The 2003 e-readiness rankings - A white paper from the Economist Intelligence Unit published by The Economist Intelligence Unit, among 60 countries, China's E-readiness have taken the 50th in 2003, only improved the ranking score of last year by one precedence. The white paper pointed out Hong Kong (10th), Singapore (12th), South Korea, 16th, Chile, 28th, Mexico, 31st, Argentina, 35th, Brazil, 36th and other developing countries and regions have had made significant advances in recent years. Comparing with our scores, we hardly keep much satisfaction; we have to keep up with the more advanced countries. Since many of the Egovernment works were carried out multi-accessed in China, so that we should continue going forward along this multi-dimensional approach, In order to build tangible architectures for E-government we shall boost high technology industries, at the same time, promote social and human society sustainable development so as to enforcing intangible architectures for E-government. Above all, the paper emphasizes the fundamental tasks for Chinese government on primary education, human resource development, equity of regional development, and poverty alleviation, points out that social and human development is the pedestal of information technology. 


\section{Conclusion}

E-government is about transformation that helps citizens and businesses find new opportunities in world market. Among other many promises, E-Government holds great potential to reform governmental bureaucracy, provide greater access to government information, offer developing opportunities to the poor on equal terms and empower them consequently, E-government will particularly benefit rural and traditionally underserved population and communities. In short, E-Government can act as a catalyst to strengthen democracy, accelerate social and economic development, and improve good governance in the country. Chinese government should take pains to reach the E-government goal, turning the country into an advanced democratic, modern information society.

\section{References}

1. Kaufmann, Daniel; Aart Kraay and Pablo Zoido-Lobaton (1999). "Governance Matters." World Bank Policy Research Working Paper No. 2196.

2. Benchmarking E-Government: A Global Perspective: Assessing the Progress of the UN Member States, a joint report of the United Nations Division for Public Economics and Public Administration and the American Society for Public Administration.

3. Al- Kibisi, G., de Boer, K., Mourshed M., and N. Rea (2001): Putting Citizens On-line, Not in line,McKinsey Quarterly, Special edition On Line Tactics, Number 2, pp. 65-73.

4. James Wolfensohn, 2001 E-Government in developing Countries, Speech at the World Bank/Development gate Way Conference.

5. Peter Lovelock and John Ure, 2003 E-Government In China .The telecommunications Research Project, University of Hong Kong, www.trp.hku.hk.

6. The 2003 e-readiness rankings A white paper from the Economist Intelligence Unit www.eiu.com

7. The e-government Handbook for developing countries, The Center for Democracy \& Technology www.cdt.org

8. Roadmap for E-government in the Developing World 10 Questions E-Government Leaders Should Ask Themselves The Working Group on E-Government in the Developing World APRIL 2002 www. pacificcouncil org 